\title{
THE FARM ECONOMIES OF THE PLAINS: COMMENT
}

\author{
William H. Meyers*
}

The paper by Belgonia and Gilbert has two distinct sections: the first section discusses the scope of income and debt problems in the Plains States and the second discusses the causes of these income and debt problems. I have the greatest concern with the last part of the paper, but I also have a few comments on the first part.

\section{Scope of Income and Debt Problem}

The evidence presented by the authors shows that financial conditions in the farm sector have deteriorated substantially since 1980 and pose a problem for the lenders as well as for the farm sector. Even more persuasive evidence of the problems is provided in farm financial survey data that has been assembled by the USDA and others. The latter studies reveal that about one-third of the farmers in the United States are in financial difficulty; and this one-third holds about two-thirds of the agricultural debt. A minority of farmers, but a much larger proportion of the total agricultural debt, are involved. The evidence also shows that these problems are more severe in the Plains States than in other regions of the country. Moreover, the data for the last few years indicates that the financial situation is not improving. It is likely to be with us for several more years.

Belongia and Gilbert point out that the income-debt problem is related to the substantial decline in asset values since 1981. Their data goes through 1985. Data available for 1986 indicates that the decline in land values is continuing. In Iowa, for example, county-average land values between 1981 and 1986 have declined in a range from 60 to 67 percent, with a 15 percent decline in 1986. As a consequence, current land values in real terms are lower than they have been at anytime during the past 40 years (Duffy and Olsen).

Both the cash flow and the financial structure aspects of the problem deserve special attention. Farmers with a large cash flow can survive a relatively large increase in debt-to-asset ratio, and farmers with relatively little debt can survive a relatively low cash flow (Jolly and Olsen). Farmers experience severe financial stress when their cash flows are negative even when they do not have a severe debt problem. Likewise, they become stressed despite a positive cash flow if their debt-to-asset ratio is

*The author is Professor of Economics and Associate Administrator of the Center for Agricultural and Rural Development, Iowa State University, Ames, Iowa. very high. This has important policy implications, since current commodity programs that address only the cash flow aspect have limited value in dealing with the overall financial problems of the farm sector.

\section{Farm Sector Dependence on Aggregate Fluctuations}

The authors set out to test whether macroeconomic fluctuations have greater impacts on agriculture-dependent economies than on nonagriculture-dependent economies. They conduct this test by regressing rates of change in GNP. I will argue that this model does not adequately test the hypothesis that the authors set out to investigate. First, the model uses only national GNP as an explanatory macroeconomic variable. Second, farm income and personal income are not appropriate measures for agricultural sector performance, since these measures are heavily influenced by government transfer payments and pricesupport programs.

There are several macroeconomic variables that have an influence on agricultural sector performance and should be candidates for explanatory variables:

\section{Interest Rate}

The farmers' interest expenses rose from about $\$ 10$ billion a year in the late 1970 s to over $\$ 20$ billion a year in the early 1980s, and in the last few years have accounted for 15 to 20 percent of total farm expenses. It is also quite likely that the interest rate has a significant indirect effect on agriculture through its effect on Third World debtservicing requirements.

\section{Exchange Rate}

The appreciation of the U.S. dollar relative to many foreign currencies in the early 1980 s made U.S. commodities less competitive with exports from competing countries. Most studies have found that these exchange-rate movements had a significant negative effect on U.S. exports and on agricultural-sector performance.

\section{GNP Growth}

This is the one variable used by the authors, and it should be expected to influence the rate of growth in domestic and foreign demand for U.S. agricultural products. 


\section{Money Supply}

Since the money supply is a policy instrument that influences all the other macroeconomic aggregates already mentioned, it is expected that changes in the rate of growth in the money supply would have an effect on agricultural-sector performance through its influence on these and other macroeconomic aggregates.

If the intent of the authors is to measure the effect of macroeconomic aggregates on the performance of the agricultural sector, then the farm income or personal income measures are not appropriate choices for the dependent variable. The reason is that the government has an agricultural policy that is basically countercyclical in its behavior. When demand slows and prices fall, government programs act to contract production, accumulate stocks, and increase transfer payments. The accumulated effect of these policy responses is to substantially insulate net farm income from these macroeconomic shocks. Thus, the relationships used by the authors to test the impact of GNP fluctuations on farm income may merely demonstrate the effectiveness of these programs in insulating farm income from these external shocks.

\section{Conclusions}

The Belongia and Gilbert test, primarily because of the choice of the dependent variable, does not tell us much about the effect that macroeconomic aggregates have on agricultural-sector performance. Perhaps it does verify that agricultural policies that have been in existence have been largely successful in insulating farm income from the effects of macroeconomic policies. It is clear, as pointed out by Belongia and Gilbert in the first part of the paper, that policies were not in place that insulated agriculturalsector financial conditions from the macroeconomic influences.

Numerous studies have found important linkages between macroeconomic shocks and performance in the agricultural sector (Bordo, Chambers, Chambers and Just, Devadoss and Meyers, Meyers et. al.). This evidence does not lead me to conclude that macroeconomic policies should be changed to favor a sector that represents about three percent of GNP. Rather, the evidence should lead us to reevaluate current agricultural policies in light of the fact that they do little to address the financial problem of farmers and agricultural lenders, which is a more serious current problem than the general farm-income problem.

\section{REFERENCES}

Belongia, Michael T. and R. Alton Gilbert. "The Farm Economics of the Plains." Paper given to Allied Social Science Association's Meeting. December, 1986.

Bordo, Michael. "The Effects of Monetary Change on Relative Commodity Prices and the Role of Long-Term Contracts." Journal of Political Economics. 88 (1980). 1088-99.

Chambers, Robert G. "Agricultural and Financial Market Interdependence in the Short-Run." American Journal of Agricultrual Economics. 66 (1984). 12-24. and Richard E. Just. "Effects of Exchange Rate Changes on U.S. Agriculture: A Dynamic Analysis." American Journal of Agricultural Economics. 63 (1981). 32-46.

Devadoss, S. and William H. Meyers. "Relative Prices and Money: Further Results for the United States." American Journal of Agricultural Economics. 69 forthcoming. November, 1987.

Duffy, Michael D. and Douglas R. Olsen. "1986 Iowa Land Value Survey: Overview." Mimeo, Cooperative Extension Service, Iowa State University. December, 1986.

Jolly, Robert W. and Douglas R. Olsen. "1986 lowa Farm Finance Survey: Summary." Mimeo, Cooperative Extension Service, Iowa State University. October, 1986.

Meyers, William H., Michael D. Helmar, S. Devadoss, Robert E. Young II and David Blandford. "Macroeconomic Impacts on the U.S. Agricultural Sector: A Quantitative Analysis for 1980-84." CARD Working Paper. 86-WP17, 1986. 